\title{
Power Quality Enhancement of Integration Photovoltaic Generator to Grid under Variable Solar Irradiance Level using MPPT-Fuzzy
}

\author{
Amirullah, Agus Kiswantono
}

Study Program of Electrical Engineering, Faculty of Engineering, University of Bhayangkara Surabaya, Indonesia

\begin{tabular}{|c|c|}
\hline Article Info & ABSTRACT \\
\hline Article history: & \multirow{13}{*}{$\begin{array}{l}\text { The paper presents power quality enhancement on low voltage of three phase } \\
\text { grid caused by PV generator integration under variabel solar irradiance level } \\
\text { on constant temperature and load. MPPT Fuzzy helps to generate duty cycle } \\
\text { to control DC/DC boost converter of PV generators. This model was } \\
\text { expected to improve power quality due to unbalance voltage and current, low } \\
\text { voltage and current harmonics, and low input power factor. There were eigth } \\
\text { scenarios PV generator connected to three phase grid using MPPT Fuzzy and } \\
\text { compared with MPPT P and O. The research results that application of two } \\
\text { methods on different irradiance and PV generator integration level produces } \\
\text { unbalanced voltage value stable at } 0 \% \text {. At the same conditions, the use of } \\
\text { MPPT Fuzzy results unbalanced current was greater than MPPT P and O. On } \\
\text { solar irradiance level fixed, the greater number of PV generator connected to } \\
\text { three-phase grid, then value of average voltage and current harmonics (THD) } \\
\text { will increases. At the level of solar radiation increases, average grid voltage } \\
\text { and current THD also have increased. The average grid voltage and current } \\
\text { THD was reduced after using MPPT Fuzzy. The application of MPPT Fuzzy } \\
\text { was able to enhance profile of grid voltage and current THD due to } \\
\text { integration of a number of PV generator to three phase grid corresponding } \\
\text { with IEEE Standard 519-1992. MPPT Fuzzy was capable to improve input } \\
\text { power factor better than MPPT P and O. }\end{array}$} \\
\hline Received Jul 24, 2016 & \\
\hline Revised Oct 24, 2016 & \\
\hline Accepted Nov 7, 2016 & \\
\hline Keyword: & \\
\hline Harmonics & \\
\hline MPPT fuzzy & \\
\hline MPPT $\mathrm{P}$ and $\mathrm{O}$ & \\
\hline Photovoltaic generator & \\
\hline Power factor & \\
\hline Power quality & \\
\hline Unbalance & \\
\hline & \\
\hline
\end{tabular}

Copyright $\odot 2016$ Institute of Advanced Engineering and Science. All rights reserved.

Corresponding Author:

Amirullah,

Study Program of Electrical Engineering,

Faculty of Enginering,

University of Bhayangkara Surabaya,

Jl. Ahmad Yani 114 Surabaya-60231, East Java Province, Indonesia.

Email: amirullah@ubhara.ac.id,am9520012003@yahoo.com

\section{INTRODUCTION}

The output power of photovoltaic (PV) array is mainly affected by solar irradiance and temperature. The output power of PV array is a function of terminal voltage and there is only one terminal voltage value where PV panels are used efficiently. The searching procedure of voltage is called maximum power point tracking (MPPT). Several algorithms have been developed to achieve MPPT technique. Theses are algorithms perturb and observe $(\mathrm{P}$ and $\mathrm{O})$, incremental conductance, open circuit voltage, short circuit current, neural network and fuzzy logic controller. PV generator required a converter for generating DC into AC power and achieve MPPT. MPPT can be achieved in one or two stages. First stage, PV array is connected to grid through a DC/AC converter and its used to obtain MPPT and generated DC voltage once. Second stages, PV array connected to grid through DC/DC and DC/AC converters. In these condition, MPPT is obtained through a DC/DC converter control PV input voltage. While PV inverter change voltage from DC/AC and keep DC/DC converter output voltage remain constant. The research of MPPT on PV 
development using artificial intelligence control algorithm which are neural network and fuzzy logic controller have already done [1]. The advantage of using both methods is to increase limit of stability and efficiency. Neural network controller takes time for learning process, resulting in a slower system response. Fuzzy logic control method is more popular than the neural network because it have more accurate, high performance, and maximum efficiency. Many studies in the field related to PV panel operation errors, especially at low solar irradiance and high temperature degree [2].

The problem of PV generator connected to grid, beside to functioning to supply power to low voltage distribution network, is also reducing electric power quality for example unbalance current and voltage, current and voltage harmonics, as well as input power factor. It caused by tracking of MPPT which is influenced by non-linear characteristic panel depends upon varying environmental condition such as temperature and solar irradiance. Another cause is presence of converter as a medium to transform DC into AC voltage for (one stage converter) as well as DC into DC and DC into AC voltage (two stage converter). The using of multilevel inverter based shunt active power filter (SAPF) to improve power quality due to PV generator system connected to grid have been implemented [3]. The proposed method can efficiently be used for reactive power compensation and reducing source current total harmonic distortion (THD) up to $0.57 \%$. The system is also capable of delivering active power with unity power factor to grid. The weakness of it were not discussing improvement harmonic voltage and PV generator connected to grid only one. Analysis of impact of PV generator connected to grid considering power quality (harmonic current) on the distribution already performed [4]. The results showed that injection of current harmonics generated by the customer side of the grid connected PV generation to still meet standart requirement. However the research did not discussed influence of PV integration on harmonics, fluctuations, and voltage flicker, as key parameter in power quality. Research on application of fuzzy logic as MPPT for controlling PV output voltage to achieve closed cycle control as smooth and fast in order to achieve maximum value power point of PV array have been already done [5]. PV systems both stand-alone and connected to grid has been modeled and simulated. The results showed that P-Q control scheme was able to provide closed control rapidly and PV system was able to generate a sinusoidal voltage with very small THD as $2.08 \%$. The weakness of research is not disscussing current THD improvement due to integration of PV to grid and number of used PV only a single.

Analysis of power quality due to integration of multi-unit of PV generator connected to three phase grid under variable solar irradiation level have been implemented [6]. Research shows that grid voltage and current on point common coupling (PCC) bus before use double tuned passive filter on condition only connect one plant is still unstable. However, if PV generator connected to three-phase grid, amounted to more than one generator, then grid voltage and current becomes unstable. At level of solar irradiation remains, the greater number of PV generator connected to three-phase grid, then average THD of grid voltage and current increases. At level of solar irradiation increases, average THD of grid voltage and current also have increased. Avarage THD of grid voltage and current reduced after double tuned passive filter installed. Nevertheless, MPPT control of PV generator still use P and $\mathrm{O}$ algorithm and did not use intelligent control. Power quality improvement of PV generator connected to three phase grid using Fuzzy Logic controller under changes in atmospheric conditions and solar radiation has been done [7]. In order to keep the system stable fuzzy logic controller is used to achieve it still has a unity power factor under all conditions. Fuzzy logic controller can improve overall system stability on a three-phase grid connected PV systems in some variation of parameters. Fuzzy logic control method is capable to reduce current THD compared to proportional integral (PI) and robust control. The value of current harmonics using PI, robust, and fuzzy logic control successively reduced from $4.05 \%, 2.08 \%$, up to $1.05 \%$ in order to achieve maximum power. However, number of PV generator connected to the grid is only single.

The research of improvement power quality on grid supplied by PV array using unified power quality conditioner (UPQC) has been done [8]. PV array is connected to the DC link of UPQC using PI compared with Fuzzy Logic controller. Power quality enhancement includes voltage sag and harmonic of voltage source. The simulation showed that fuzzy controller on UPQC and PV array is able to improve the quality of source voltage better than PI controller. The grid voltage using PI and Fuzzy controller results THD voltage as 7.06 and $1.36 \%$ respectively. The research does not address improvement of load current quality due to a combination UPQC and the PV array. The method of Parallel Active Power Filter (PAPF) using PV cells energy to feed linear or nonlinear loads with current perturbations compensation and the excess of the energy have been proposed [9]. As a result of using instantaneous p-q theory as a control scheme, the multi function operation such as harmonic elimination, reactive power control and uninterruptible power supply will be achieved. The system consists of PV cells, connected to a diode rectifier feeding a parallel active power filter. The simulation results prove the efficiency of using the proposed method for PV cells energy injection and power quality improvement in the grid power system.

The purposes of research is to enhance power quality on low voltage of three phase grid caused by PV generator integration under variabel solar irradiance level on constant temperature and load using fuzzy 
logic controller. Model of PV generator system in singular to three-phase output voltage and connected three phase grid. DC/DC converter consists of a boost converter that functions to raise DC output voltage of PV generator. The DC output voltage of boost converter circuit is then converted by the DC/AC inverter based pulse width modulation (PWM) algorithm into a three-phase AC voltage to three-phase grid. Then single PV generator is modeled and used to create multi PV generator connected to grid through a three-phase distribution transformer. Analysis of research includes effect of solar irradiance and integration of a number of PV generator to power quality on constant temperature and load. There are two scenarios PV generator connected to three-phase grid. They are using MPPT algorithm P and O and MPPT with Fuzzy Logic controller (MPPT Fuzzy). Each MPPT controller has four scenarios, then for a total has eight scenarios of PV generator integration level. Futhermore is to determine unbalance voltage and current, voltage and current THD, and power factor input on PCC bus of low-voltage three-phase grid. The final process is to validate the results of research refers ANSI/IEEE 241-1990 Standard (voltage and current unbalanced), IEEE 519-1992 Standard (voltage and current harmonics grid), and PLN Standard (input power factor).

The rest of this paper is organized as follow. Section 2 shows proposed model of single and three PV generator system connected to three-phase grid, MPPT P and O method, MPPT Fuzzy method, unbalance voltage and currect, power quality and harmonics, as well as power factor correction. Section 3 describes influence of solar irradiance and integration of PV generator to voltage and current unbalance, voltage and current THD of three phase grid, as well as input power factor on constant temperature and load using MPPT $\mathrm{P}$ and $\mathrm{O}$ and MPPT Fuzzy method. In this section, example cases studied are presented and the results are verified with those of Matlab/Simulink. Finally, the paper in concluded in Section 4.

\section{RESEARCH METHOD}

\subsection{Research Procedure}

Figure 1 shows model PV generator connected to three phase grid using MPPT with Fuzzy Logic Controller (MPPT Fuzzy). Model of PV generator system in singular to three-phase output voltage and connected three-phase grid. DC/DC converter consists of a boost converter that functions to raise DC output voltage of PV generator. DC output voltage of boost converter circuit is then converted by the DC/AC inverter into a three-phase AC voltage to three-phase grid. Then single PV generator is modeled and used to create multi PV generator connected to grid through a three-phase distribution transformer (Figure 2). The study used three groups of PV generator model with an active power of $100 \mathrm{~kW}$ each. Beside that, PV generator is also connected on three groups of three phase load with active power $20 \mathrm{~kW}$ respectively.

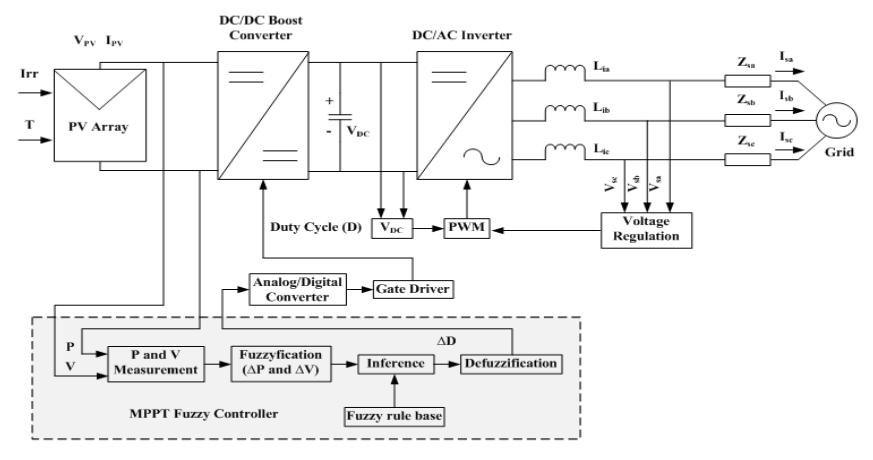

Figure 1. Single PV Generator Connected Three Phase Grid Using MPPT Fuzzy

The paper presents power quality enhancement on low voltage of three phase grid caused by PV generator integration under variabel solar irradiance level on constant temperature and load. Fuzzy logic controller helps to generate duty cycle (D) with a variable step to control DC/DC boost converter and subsequently result in rapid convergence calculations and more stable to determine MPPT of PV generator. DC/DC converter generate a DC voltage that will be as input to DC/AC converter using PWM. This model is expected to reduce losses due to unbalance voltage and current, low voltage and current harmonics, and low input power factor. There are two scenarios PV generator connected to three-phase grid. They are using MPPT algorithm P and O and MPPT with Fuzzy Logic Controller (MPPT Fuzzy). Each MPPT control has four scenarios, then for a total has eight scenarios of PV generator integration level. Power quality aspects studied are unbalance voltage and current, voltage and current THD, and power factor input on PCC bus on

Power Quality Enhancement of Integration Photovoltaic Generator to Grid under Variable ... (Amirullah) 
eight scenarios using (a) MPPT P and O (b) MPPT Fuzzy as follow four conditions respectively (i) irradiance $400 \mathrm{~W} / \mathrm{m} 2$, (ii) irradiance $600 \mathrm{~W} / \mathrm{m} 2$, (iii) irradiance $800 \mathrm{~W} / \mathrm{m} 2$, and (iv) irradiance $1000 \mathrm{~W} / \mathrm{m} 2$ on condition 1, 2, and 3 of model PV generator connected to three phase grid. Futhermore is to determine unbalance voltage and current, voltage and current THD, and power factor input on each scenarios. The final process is to validate the results of research refers ANSI/IEEE 241-1990 Standard (voltage and current unbalanced), IEEE 519-1992 Standard (voltage and current harmonics grid), and PLN Standard (input power factor).

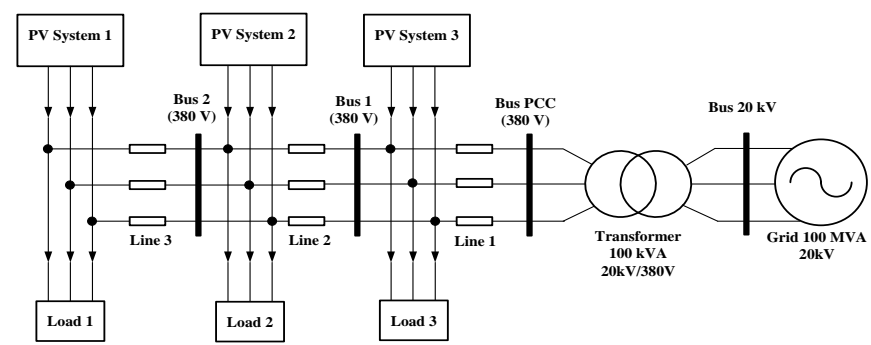

Figure 2. Proposed Model of Three PV Generator System Connected Three Phase Grid

Table 1 shows simulation parameters of three models PV generators connected to three phase grid.

Table 1. Simulation Parameters

\begin{tabular}{|c|c|c|}
\hline Equipment & Parameters & Design Value \\
\hline PV generator & Power & $100 \mathrm{~kW}$ \\
\hline \multirow{2}{*}{1,2 , and 3} & Temperature & $40^{\circ} \mathrm{C}$ \\
\hline & Irradiance & $400,600,800,1000 \mathrm{~W} / \mathrm{m}^{2}$ \\
\hline \multirow[t]{3}{*}{ Three phase grid } & MVA short circuit & 100 MVA \\
\hline & Voltage (line) & 380 volt \\
\hline & Frequency & $50 \mathrm{~Hz}$ \\
\hline \multirow{3}{*}{$\begin{array}{l}\text { Three phase distribution } \\
\text { transformer }\end{array}$} & Rated Power & $100 \mathrm{kVA}$ \\
\hline & Frequency & $50 \mathrm{~Hz}$ \\
\hline & Rated voltage & $380 \mathrm{Volt} / 20 \mathrm{kV}$ \\
\hline \multirow[t]{4}{*}{ Load 1, 2, 3} & Type & Two winding \\
\hline & Active power & $20 \mathrm{~kW}$ \\
\hline & Voltage (line) & 380 Volt \\
\hline & Frequency & $50 \mathrm{~Hz}$ \\
\hline \multirow[t]{3}{*}{ Low voltage lines $1,2,3$} & Resistance & $\mathrm{R}=0,1273 \mathrm{Ohm} / \mathrm{km}$ \\
\hline & Inductance & $\mathrm{L}=93,37 \mathrm{mH} / \mathrm{km}$ \\
\hline & Capacitance & $\mathrm{C}=1,274 \mu \mathrm{F} / \mathrm{km}$ \\
\hline \multirow[t]{3}{*}{ Low voltage distribution line } & Line 1 & $1 \mathrm{~km}$ \\
\hline & Line 2 & $1 \mathrm{~km}$ \\
\hline & Line 3 & $1 \mathrm{~km}$ \\
\hline DC link capacitor & Capacitance & $2000 \mu \mathrm{F}$ \\
\hline PWM generator for DC/AC & Frequency & $4 \mathrm{kHz}$ \\
\hline Inverter & Sampling time & $5 \times 10^{-6}$ second \\
\hline Fuzzy inference system & Method & Mamdani \\
\hline Fuzzy model & Composition & Max-Min \\
\hline \multirow[t]{2}{*}{ Input membership function } & Delta voltage & gbellmf, trimf \\
\hline & Delta power & gbellmf, trimf \\
\hline Output membership function & Delta duty cycle & trimf \\
\hline
\end{tabular}

\subsection{Photovoltaic Model}

Figure 3 shows the equivalent circuit of a solar panel. A solar panel is composed of several PV cells that have series or parallel or series-parallel external connections [10]. 


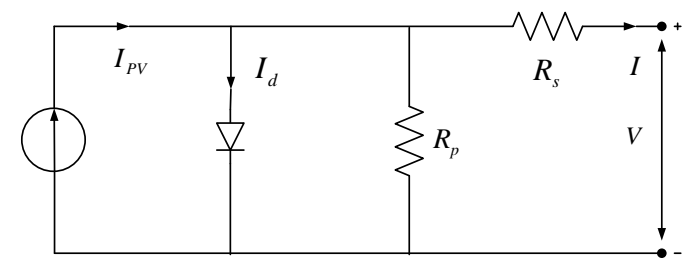

Figure 3. Equivalent Circuit of Solar Panel

The V-I characteristic of a solar panel is showed in Equation 1 [10] :

$$
I=I_{P V}-I_{o}\left[\exp \left(\frac{V+R_{S} I}{a V_{t}}\right)-1\right]-\frac{V+R_{S} I}{R_{P}}
$$

where $I_{P V}$ is the photovoltaic current, $I_{o}$ is saturated reverse current, 'a' is the ideal diode constant, $V_{t}=N_{S} K T q^{-1}$ is the thermal voltage, $N_{S}$ is the number of series cells, $q$ is the electron charge, $K$ is the Boltzmann constant, $T$ is the temperature of $\mathrm{p}-\mathrm{n}$ junction, $R_{S}$ and $R_{P}$ are series and parallel equivalent resistance of the solar panels. $I_{P V}$ has a linear relation with light intensity and also varies with temperature variations. $I_{o}$ is dependent on temperature variations. The values of $I_{p v}$ and $I_{o}$ are calculated as following Equation 2 and 3:

$$
\begin{aligned}
& I_{P V}=\left(I_{P V, n}+K_{1} \Delta T\right) \frac{G}{G_{n}} I \\
& I_{o}=\frac{I_{S C, n}+K_{I} \Delta T}{\exp \left(V_{O C, n}+K_{V} \Delta T\right) / a V_{t}-1}
\end{aligned}
$$

In which $I_{P V, n}, I_{S C, n}$ and $V_{O C, n}$ are photovoltaic current, short circuit current and open circuit voltage in standard conditions $\left(T_{n}=25 \mathrm{C}\right.$ and $\left.G_{n}=1000 \mathrm{Wm}^{-2}\right)$ respectively. $K_{I}$ is the coefficient of short circuit current to temperature, $\Delta T=T-T_{n}$ is the temperature deviation from standard temperature, $G$ is the light intensity and $K_{V}$ is the ratio coefficient of open circuit voltage to temperature. Open circuit voltage, short circuit current and voltage-current corresponding to the maximum power are three important points of $\mathrm{I}-\mathrm{V}$ characteristic of solar panel. These points are changed by variations of atmospheric conditions. By using Equation 4 and 5 which are derived from PV model equations, short circuit current and open circuit voltage can be calculated in different atmospheric conditions.

$$
\begin{aligned}
& I_{S C}=\left(I_{S C}+K_{1} \Delta T\right) \frac{G}{G_{n}} \\
& V_{O C}=V_{O C}+K_{V} \Delta T
\end{aligned}
$$

\subsection{MPPT P and $O$ and MPPT Fuzzy}

The initial research is to determine value of duty cycle (D) with a variable step to control DC/DC boost converter circuit with MPPT P and O algorithm. For PV converter, maximum power available is determined by PV cell characteristics, but this value often mismatches with the maximum power point (MPP) of the load. By implementing MPPT in PV systems, MPP in PV cells can be maintained so that the number and size of PV panels can be reduced or energy yield can be optimized [11].

Due to moving of sun, which leads to change in irradiance, PV panels angle and variation of irradiance reaching the panels, energy generated from PV panels are absorbed does not constant over time. When this condition occurs, the VI characteristics changes and MPP will move. If the system was previously operating at MPP, there will most probably a power loss with the same operating point and new condition. To overcome these problems, MPPT has been developed. The system includes no moving parts (where the modules are moved to track the sun). MPPT search for the maximum power independent based on environmental conditions (following changes in solar radiation and temperature) and maintain the PV terminal voltage remains constant at maximum value. The most used method of MPPT is Perturb and

Power Quality Enhancement of Integration Photovoltaic Generator to Grid under Variable ... (Amirullah) 
Observe ( $\mathrm{P}$ and $\mathrm{O})$ that algorithm is shown in Figure 4 [12]. Figure 5 shows Matlab/Simulink model for control MPPT using $\mathrm{P}$ and $\mathrm{O}$ algorithm.

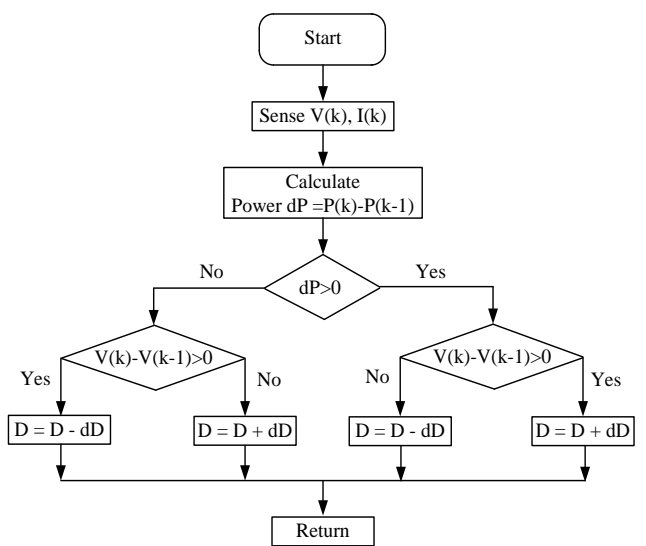

Figure 4. P and $\mathrm{O}$ Algorithm

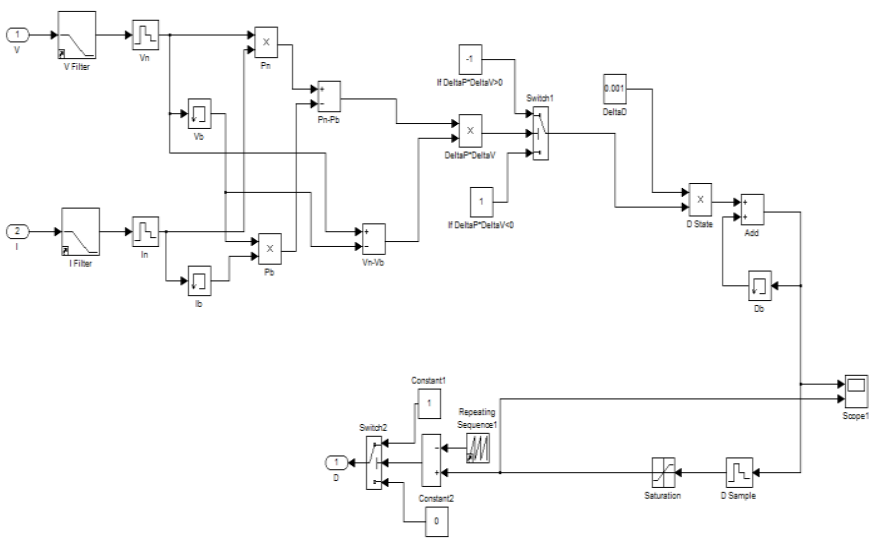

Figure 5. Matlab/Simulink Model for MPPT Using P and O Algorithm

The next process is to perform same procedure for determining it using MPPT Fuzzy method showed in Figure 1. Fuzzy logic controller have been widely used in industrial process in the resent years due to their heuristic nature associated with simplicity, effectiveness and its multi-rule-based variable's consideration for both linear and non-linear parameter variation of the system. Fuzzy system is composed of knowledge based rules system; the main part of Fuzzy Logic controller is knowledge of base consisting of the If-Then rules. Fuzzy Logic is implemented to obtain the MPP operation voltage point faster with less overshoot and also it can minimize the voltage fluctuation after MPP has been recognized. It also is capable to enhance power quality problem for example unbalance current and voltage, current and voltage harmonics, as well as input power factor. The control objective is to track maximum power will lead consequently to effective operation of the PV panel. To design the FLC, variables which represent the dynamic performance of the system should be chosen as the input to the controller. The basic block diagram implemented in Fuzzy Logic Controller is shown in Figure 6 [12].

Due account MPPT Fuzzy method is in terms of intelligence and speed. Fuzzy MPPT method is done by determining input variables, namely fuzzy control output power $(\Delta \mathrm{P})$ and output voltage $(\Delta \mathrm{V}) \mathrm{PV}$ generator, seven linguistic variables fuzzy sets, fuzzy operating system block (fuzzyfication, fuzzy rule base, and defuzzyfication), Function $\Delta \mathrm{P}$ and $\Delta \mathrm{V}$ during fuzzyfication, a table fuzzy rule base, crisp values to determine duty cycle (D) in defuzzyfication phase with variable step to control DC/DC boost converter circuit. Figure 7 shows Matlab/Simulink model for control MPPT using Fuzzy Logic Controller.

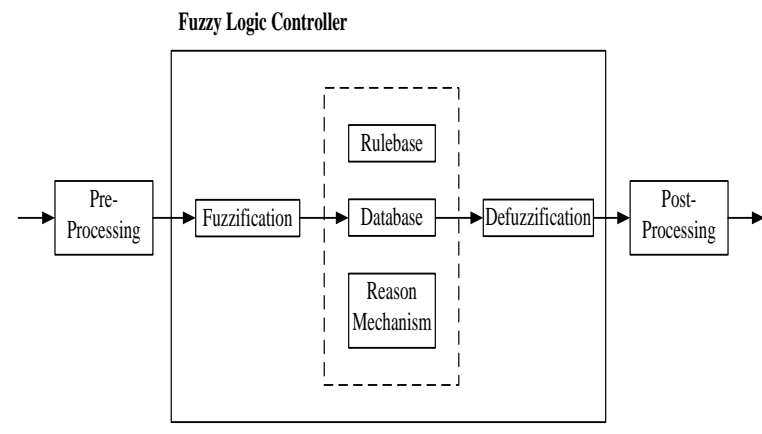

Figure 6. Blok Diagram of Fuzzy Logic Controller

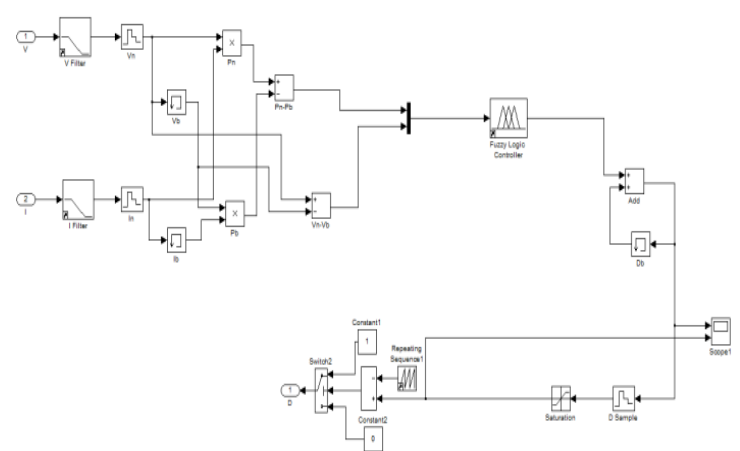

Figure 7. Matlab/Simulink Model for MPPT using Fuzzy Logic Controller 
At fuzzyfication phase shown in Figure 6, a number of input variables is calculated and converted into a linguistic variable based on the subset called membership function (MF). To translate value of voltage change and power change in, input fuzzy "change of voltage" and "change of power" is designed to use seven fuzzy variable called PB (Positive Big), PM (Positive Medium), NS (Negative Small), PS (Positive Small) ZE (Zero), NM (Negative Medium), and Negative Big (NB). Voltage change $(\Delta \mathrm{V})$ and power changes $(\Delta \mathrm{P})$ is a proposed system input variables and output variable fuzzy logic control is duty cycle change value $(\Delta \mathrm{D})$. Membership function voltage changes, power changes, and duty cycle change, each shown in Figure 8 up to 10 . Limit of input and output membership functions, determined by prior knowledge of parameter variations.

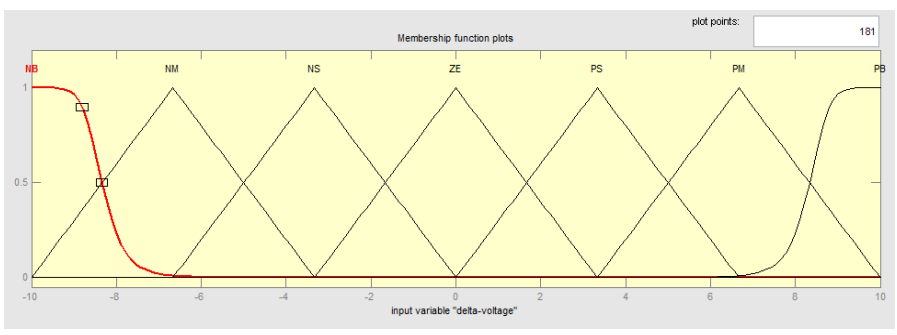

Figure 8. Input Variable Voltage Change (Delta Voltage)

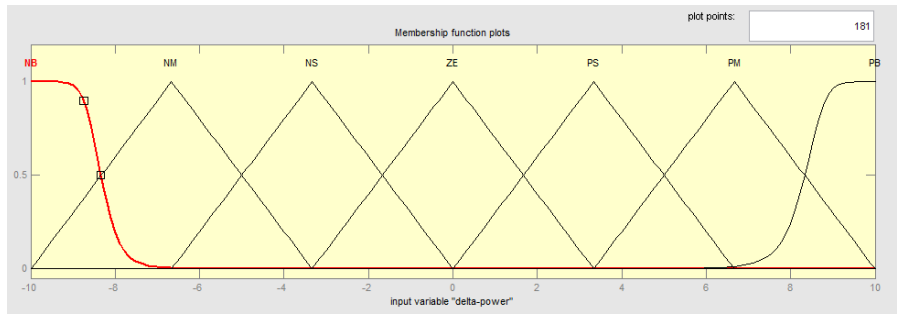

Figure 9. Input Variable Power Change (Delta Power)

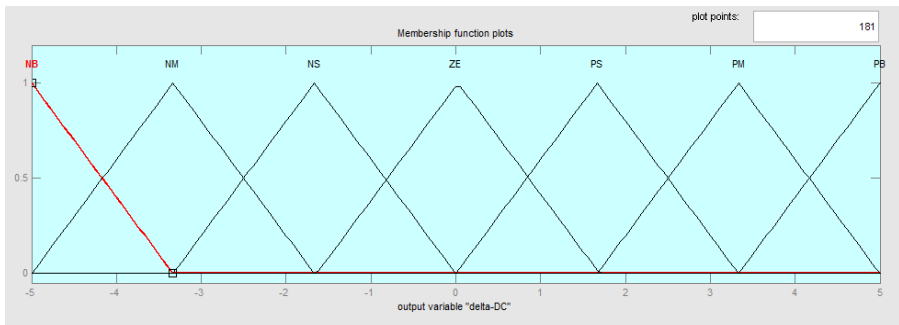

Figure 10. Output Variable Duty Cycle Change (Delta D)

The fuzzy rule algorithm collects a number of fuzzy control rules in a specific order. This rule is used to control system to meet desired performance requirements, and they are designed from a knowledge of intelligent control systems. The fuzzy inference of fuzzy logic controller using a method that relates to a composition Mamdani Max-Min. Fuzzy inference system in fuzzy logic controller consists of three parts, namely rule base, database, and reasoning mechanism (Figure 6). Rule base consists of a number of If-Then rule for proper operation of controller. The If side of rule is called antecedent and Then side is called consequence. These rules may be regarded as similar response made by human thought processes and controllers using linguistic input variables, obtained after fuzzyfication for the operation of these rules. The database consists of all user-defined membership function to be used in a number of these rules. Reasoning mechanism basically given processing rules based on specific rules and given conditions provides us the required result.

After determine $\Delta \mathrm{V}$ and $\Delta \mathrm{P}$ value, that value is then converted into linguistic variables and use them as input functions for fuzzy logic controller. The output value is $\Delta \mathrm{D}$ is generated using block inference and

Power Quality Enhancement of Integration Photovoltaic Generator to Grid under Variable ... (Amirullah) 
fuzzy logic controller rules as shown in Table 2. Finally defuzzyfication block operates to change value of $\Delta \mathrm{D}$ is raised from linguistic variables into numeric variables back. Numeric variables that become inputs signal for the IGBT switch of DC/DC boost converter to be able to determine MPPT value for each generation PV accurately at the same time also improve power quality as a result of integration of three PV generator to low voltage three phase grid.

Table 2. Fuzzy Rules

\begin{tabular}{|c|c|c|c|c|c|c|c|}
\hline$\Delta \mathrm{V}$ & NB & NM & NS & $\mathrm{ZE}$ & PS & PM & PB \\
\hline NB & PB & PM & PS & NS & NS & NM & NB \\
\hline NM & PM & PS & PS & NS & NS & NS & NM \\
\hline NS & PS & PS & PS & NS & NS & NS & NM \\
\hline $\mathrm{ZE}$ & NS & NS & PS & $\mathrm{ZE}$ & $\mathrm{ZE}$ & NS & NS \\
\hline PS & NS & NS & NS & PS & PS & PS & PS \\
\hline PM & NM & NM & NS & PS & PS & PS & PS \\
\hline PB & NB & NB & NM & PS & PS & PM & PB \\
\hline
\end{tabular}

\subsection{Harmonic}

Power quality means quality of voltage and current. Quality is determined based on the voltage and current value or the tolerance limit of equipment used. In general, current and voltage wave form of pure sinusoidal waves. One problem that occurs is non sinusoida or distorted current and voltage waves generated by harmonics in the power system [15]. Harmonic is distorted periodic steady state wave caused by the interaction between the shape of a sine wave at the fundamental frequency system with another wave component which is an integer multiples frequency of fundamental frequency. The most common harmonic index, which relates to the voltage waveform, is the total harmonic distortion (THD), which is defined as the root mean square (rms) of the harmonics expressed as a percentage of the fundamental component as showed in Equation 6. For most applications, it is sufficient to consider the harmonic range from the 2nd to 25th, but most standards specify up to the 50th [13]. Second harmonic index is current THD means the ratio of rms harmonic current value to rms fundamental current which expressed in Equation 7 [14].

$$
\begin{aligned}
& T H D_{V}=\frac{\sqrt{\sum_{n=2}^{N} V_{n}^{2}}}{V_{1}} \times 100 \% \\
& T H D_{I}=\frac{\sqrt{\sum_{n=2}^{N} I_{n}^{2}}}{I_{1}} \times 100 \%
\end{aligned}
$$

where $V_{n}$ and $I_{n}$ (the rms voltage and current at harmonic $n$ ), $V_{l}$ and $I_{l}$ (the fundamental rms voltage and current), $N$ (the maximum harmonic order to be considered). The allowable maximum THD value for each country is different depending on the standard used. THD standards most often used in electric power system is IEEE Standard 519-1992. There are two criteria used in the analysis of harmonic distortion that voltage distortion limit and current distortion limit [15].

\subsection{Voltage and Current Unbalance}

There are several standards that can be used to determine level of voltage unbalance in three-phase systems, e.g. IEC, NEMA, and IEEE. In this study, value of unbalance voltage use Equation 8 is based ANSI/IEEE 241-1990 Standard [16] as follows:

$$
V(\%)=\frac{\left|V_{\text {avarage }}-V_{a, b, c \min o r \max }\right|}{V_{\text {avarage }}} \times 100 \%
$$

By using Equation 8, value of unbalance voltage expressed in percent (\%) and is defined as follows; $\mathrm{V}_{\text {avarage }}$

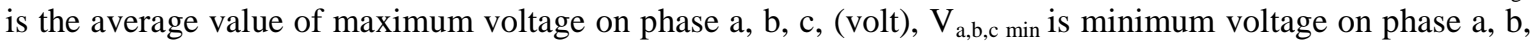


$\mathrm{c}$, (volt), $\mathrm{V}_{\mathrm{a}, \mathrm{b}, \mathrm{c} \text { max }}$ is maximum voltage on phase $\mathrm{a}, \mathrm{b}, \mathrm{c}$ (volt ). By using the same equation, then percentage of unbalance current can be calculated by replacing voltage magnitude into current magnitude.

\subsection{Power Factor Correction}

Power factor correction (PFC) can be obtained based on value input harmonic distortion (THD) source current. Equation 9 shows input power factor as a function of source current THD [17]. Power factor is input power factor and $\mathrm{THD}_{\mathrm{I}}$ is current harmonics expressed in percent.

$$
P F=\frac{1}{\sqrt{1+\left(\frac{T H D_{I}(\%)}{100}\right)^{2}}}
$$

\section{RESULTS AND ANALYSIS}

Analysis of results starts from determination maximum and minimum voltage grid on each phase, unbalance voltage using Equation 8, as well as voltage THD in three phase grid on PCC bus respectively, using MPPT $\mathrm{P}$ and $\mathrm{O}$ and MPPT Fuzzy. By using the same procedure subsequently obtained unbalance current value, current THD, and input power factor using Equation 9, based on grid current THD obtained previously. Table 3 show voltage unbalance and average voltage harmonic $\left(\mathrm{THD}_{\mathrm{V}}\right)$ grid in three model integration of PV generator and four different levels of radiation connected to three phase grid using MPPT P and $\mathrm{O}$ and MMPT Fuzzy. Table 4 shows unbalance current, average current harmonic $\left(\mathrm{THD}_{\mathrm{I}}\right)$, and input power factor on PCC bus at the same condition.

Table 3. Unbalance Voltage and Average Voltage Harmonic $\left(\mathrm{THD}_{\mathrm{V}}\right)$ grid

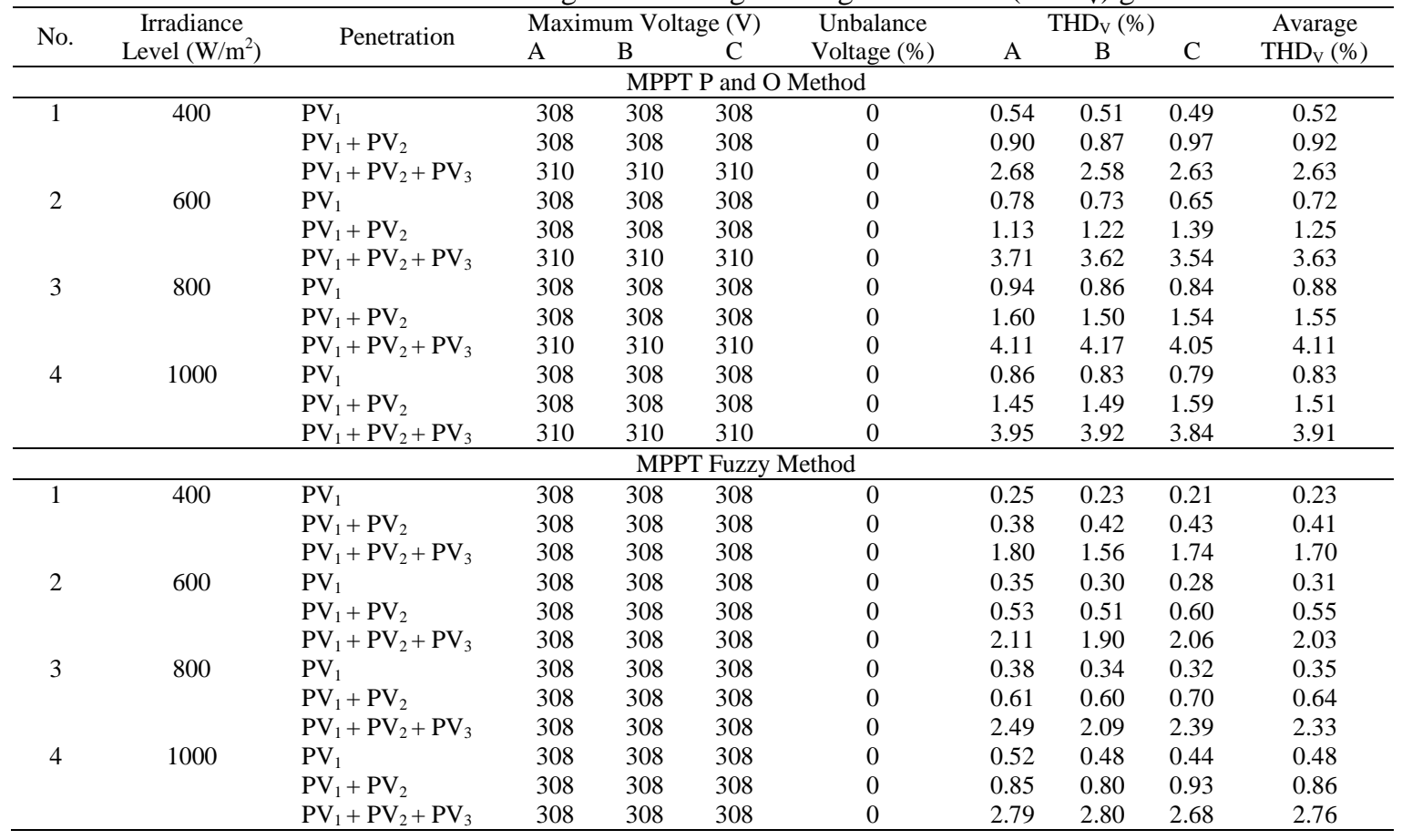


Table 4. Unbalance Current, Average Current Harmonic (THD $)$, and Input Power Factor

\begin{tabular}{|c|c|c|c|c|c|c|c|c|c|c|c|}
\hline \multirow[b]{2}{*}{ No. } & \multirow{2}{*}{$\begin{array}{c}\text { Irradiance } \\
\text { Level } \\
\left(\mathrm{W} / \mathrm{m}^{2}\right)\end{array}$} & \multirow[b]{2}{*}{ Penetration } & \multicolumn{3}{|c|}{ Maximum Current (A) } & \multirow{2}{*}{$\begin{array}{c}\text { Unbalance } \\
\text { Current }(\%)\end{array}$} & \multicolumn{3}{|c|}{ THD $_{\text {I }}(\%)$} & \multirow{2}{*}{$\begin{array}{c}\text { Avarage } \\
\text { THD }_{\text {I }}(\%)\end{array}$} & \multirow{2}{*}{$\begin{array}{c}\text { Avarage } \\
\text { PF (\%) }\end{array}$} \\
\hline & & & A & B & $\mathrm{C}$ & & A & B & $\mathrm{C}$ & & \\
\hline & \multicolumn{11}{|c|}{ MPPT P and O Method } \\
\hline \multirow[t]{3}{*}{1} & 400 & $\mathrm{PV}_{1}$ & 9.69 & 9.69 & 9.69 & 0 & 0.07 & 0.08 & 0.06 & 0.07 & 99.999 \\
\hline & & $\mathrm{PV}_{1}+\mathrm{PV}_{2}$ & 9.60 & 9.50 & 9.80 & 1.7300 & 0.24 & 0.24 & 0.34 & 0.28 & 99.999 \\
\hline & & $\mathrm{PV}_{1}+\mathrm{PV}_{2}+\mathrm{PV}_{3}$ & 12.5 & 10.0 & 10.0 & 15.385 & 2.01 & 1.27 & 1.69 & 1.66 & 99.986 \\
\hline \multirow[t]{3}{*}{2} & 600 & $\mathrm{PV}_{1}$ & 9.70 & 9.70 & 9.70 & 0 & 0.10 & 0.11 & 0.10 & 0.11 & 99.999 \\
\hline & & $\mathrm{PV}_{1}+\mathrm{PV}_{2}$ & 9.60 & 9.50 & 9.80 & 1.7300 & 0.35 & 0.24 & 0.39 & 0.33 & 99.999 \\
\hline & & $\mathrm{PV}_{1}+\mathrm{PV}_{2}+\mathrm{PV}_{3}$ & 12.5 & 10.0 & 10.0 & 15.385 & 2.24 & 1.48 & 1.83 & 1.85 & 99.983 \\
\hline \multirow[t]{3}{*}{3} & 800 & $\mathrm{PV}_{1}$ & 9.70 & 9.70 & 9.70 & 0 & 0.13 & 0.14 & 0.13 & 0.13 & 99.999 \\
\hline & & $\mathrm{PV}_{1}+\mathrm{PV}_{2}$ & 9.60 & 9.50 & 9.80 & 1.7300 & 0.44 & 0.31 & 0.40 & 0.38 & 99.999 \\
\hline & & $\mathrm{PV}_{1}+\mathrm{PV}_{2}+\mathrm{PV}_{3}$ & 12.5 & 10.0 & 10.0 & 15.385 & 2.28 & 1.56 & 1.93 & 1.94 & 99.982 \\
\hline \multirow[t]{4}{*}{4} & 1000 & $\mathrm{PV}_{1}$ & 9.70 & 9.70 & 9.70 & 0 & 0.12 & 0.14 & 0.13 & 0.13 & 99.999 \\
\hline & & $\mathrm{PV}_{1}+\mathrm{PV}_{2}$ & 9.60 & 9.50 & 9.80 & 1.7300 & 0.39 & 0.32 & 0.41 & 0.38 & 99.999 \\
\hline & & $\mathrm{PV}_{1}+\mathrm{PV}_{2}+\mathrm{PV}_{3}$ & 12.5 & 10.0 & 10.0 & 15.385 & 2.31 & 1.61 & 1.85 & 1.93 & 99.982 \\
\hline & \multicolumn{11}{|c|}{ MPPT-Fuzzy Method } \\
\hline \multirow[t]{3}{*}{1} & 400 & $\mathrm{PV}_{1}$ & 9.68 & 9.69 & 9.70 & 0.1032 & 0.06 & 0.05 & 0.02 & 0.04 & 99.999 \\
\hline & & $\mathrm{PV}_{1}+\mathrm{PV}_{2}$ & 9.50 & 9.40 & 9.70 & 1.3940 & 0.12 & 0.32 & 0.34 & 0.26 & 99.999 \\
\hline & & $\mathrm{PV}_{1}+\mathrm{PV}_{2}+\mathrm{PV}_{3}$ & 12.5 & 9.50 & 9.50 & 19.048 & 1.79 & 1.19 & 1.57 & 1.52 & 99.988 \\
\hline \multirow[t]{3}{*}{2} & 600 & $\mathrm{PV}_{1}$ & 9.68 & 9.69 & 9.70 & 0.1032 & 0.06 & 0.06 & 0.03 & 0.05 & 99.999 \\
\hline & & $\mathrm{PV}_{1}+\mathrm{PV}_{2}$ & 9.60 & 9.40 & 9.70 & 1.3940 & 0.15 & 0.30 & 0.34 & 0.26 & 99.999 \\
\hline & & $\mathrm{PV}_{1}+\mathrm{PV}_{2}+\mathrm{PV}_{3}$ & 12.5 & 9.50 & 9.50 & 19.048 & 1.87 & 1.18 & 1.60 & 1.55 & 99.988 \\
\hline \multirow[t]{3}{*}{3} & 800 & $\mathrm{PV}_{1}$ & 9.68 & 9.69 & 9.70 & 0.1032 & 0.06 & 0.06 & 0.03 & 0.05 & 99.999 \\
\hline & & $\mathrm{PV}_{1}+\mathrm{PV}_{2}$ & 9.68 & 9.40 & 9.70 & 1.3940 & 0.16 & 0.29 & 0.35 & 0.26 & 99.999 \\
\hline & & $\mathrm{PV}_{1}+\mathrm{PV}_{2}+\mathrm{PV}_{3}$ & 12.5 & 9.50 & 9.50 & 19.048 & 1.65 & 0.86 & 1.69 & 1.40 & 99.990 \\
\hline \multirow[t]{3}{*}{4} & 1000 & $\mathrm{PV}_{1}$ & 9.68 & 9.69 & 9.70 & 0.1032 & 0.06 & 0.08 & 0.05 & 0.06 & 99.999 \\
\hline & & $\mathrm{PV}_{1}+\mathrm{PV}_{2}$ & 9.60 & 9.40 & 9.70 & 1.3940 & 0.21 & 0.23 & 0.32 & 0.26 & 99.999 \\
\hline & & $\mathrm{PV}_{1}+\mathrm{PV}_{2}+\mathrm{PV}_{3}$ & 12.5 & 9.50 & 9.50 & 19.048 & 2.06 & 1.26 & 1.70 & 1.68 & 99.986 \\
\hline
\end{tabular}

Figure 11 shows grid voltage on two models of PV generator integration connected to three phase grid under solar irradiance $1000 \mathrm{~W} / \mathrm{m} 2$ on PCC bus using MPPT P and O, and MPPT Fuzzy method.

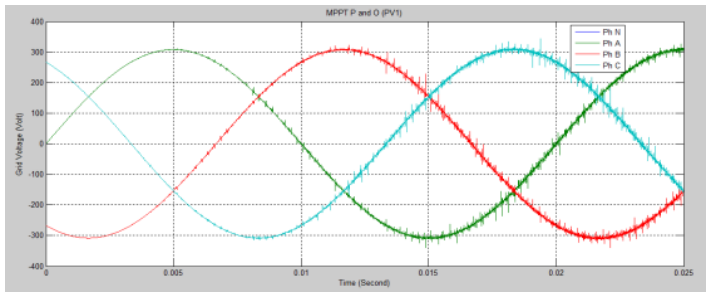

(i) MPPT P and O

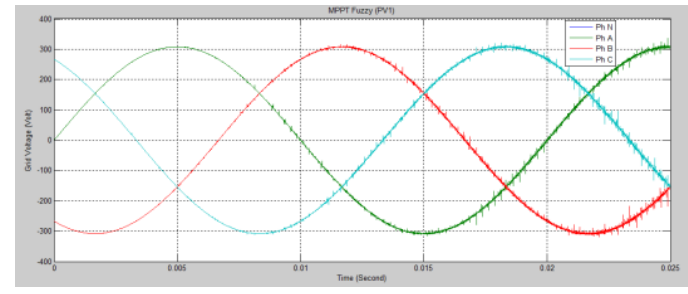

(ii) MPPT Fuzzy

(a) PV1

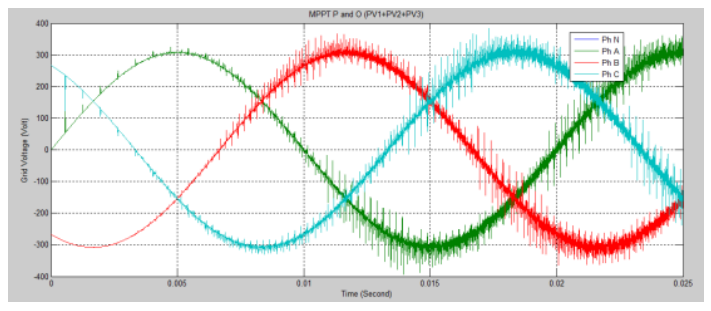

(i) MPPT P and O



(ii ) MPPT Fuzzy

(b) PV1+PV2+PV3

Figure 11. Simulation Results of Grid Voltage on Two Models of PV Generator Integration Connected to Three Phase Grid Under Solar Irradiance $1000 \mathrm{~W} / \mathrm{m} 2$ on PCC Bus 
Figure 12 shows harmonics spectrum of grid voltage on two models of PV generator integration connected to three phase grid under solar irradiance $1000 \mathrm{~W} / \mathrm{m} 2$ on PCC bus using MPPT P and O, and MPPT Fuzzy method.

Figure 13 shows curves of average voltage harmonics $\left(\mathrm{THD}_{\mathrm{V}}\right)$ on three models of PV generator integration and four levels of solar irradiance level connected three-phase grid on PCC bus using MPPT P and $\mathrm{O}$, and MPPT Fuzzy method.

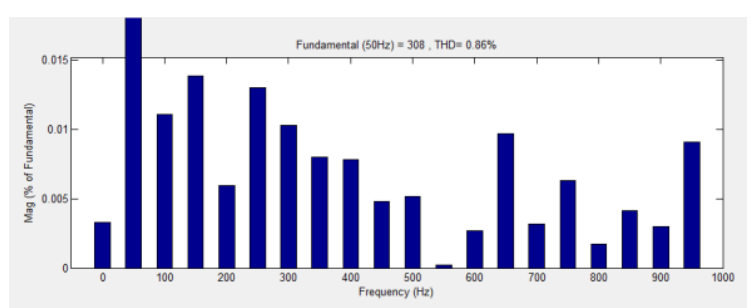

(i) MPPT P and O

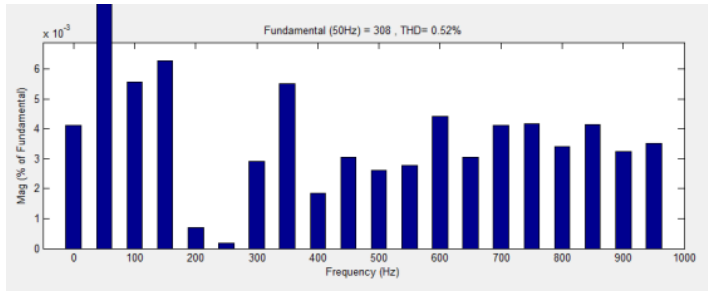

(ii) MPPT Fuzzy

(a) PV1

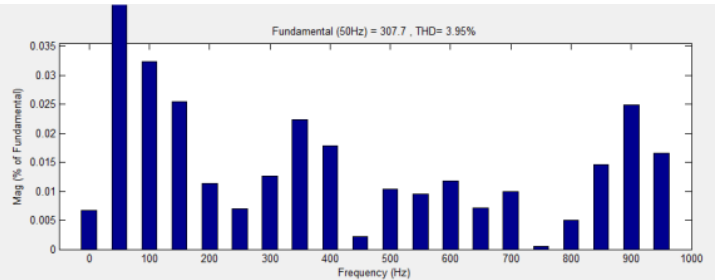

(i) MPPT P and O

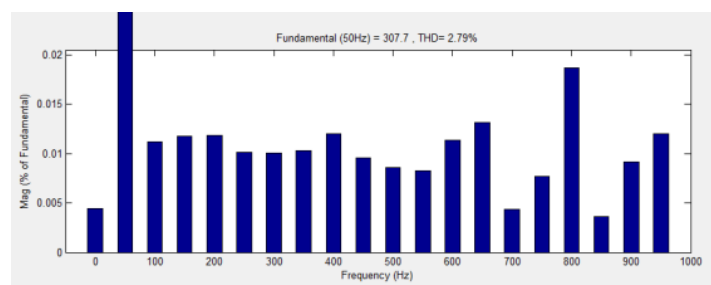

(ii ) MPPT Fuzzy

(b) PV1+PV2+PV3

Figure 12. Harmonics Spectrum of Grid Voltage on Two Models of PV Generator Integration Connected to Three Phase Grid Under Solar Irradiance $1000 \mathrm{~W} / \mathrm{m} 2$ on PCC Bus
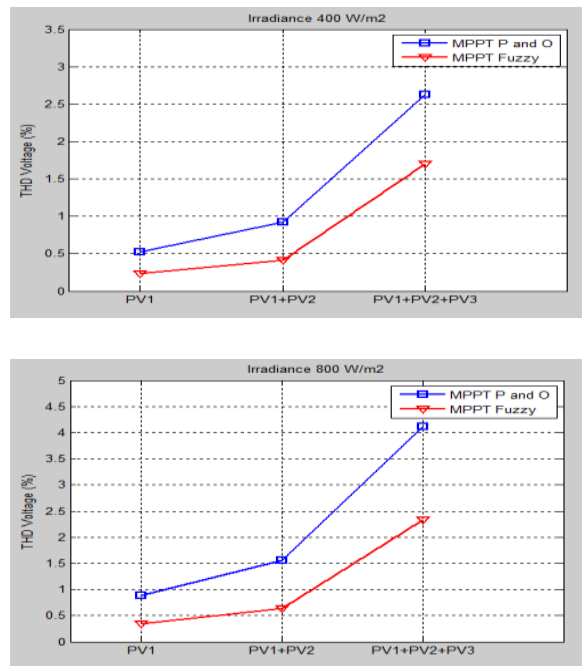
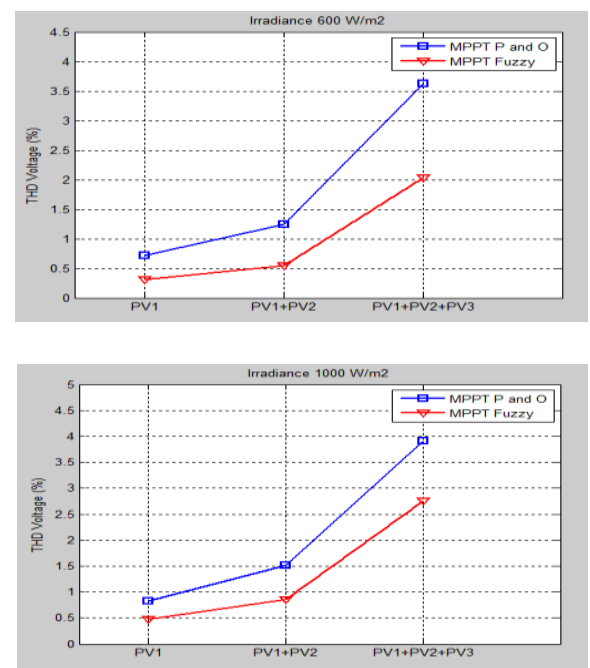

Figure 13. Average Voltage Harmonics $\left(\mathrm{THD}_{\mathrm{V}}\right)$ on Three Models of PV Generator Integration under Solar Irradiance Level from 400 to $1000 \mathrm{~W} / \mathrm{m}^{2}$

Table 3 shows that nominal grid voltage before using MPPT P and O method on the condition only connected to single generator (PV1) and two generators (PV1 + PV2) is still stable each as 308 volt. However, if PV generator connected to three phase grid equal as three (PV1 + PV2 + PV3), then grid voltage 
on bus PCC bus rises to 310 volt or $0.65 \%$. MPPT P and $\mathrm{O}$ method results a nominal voltage unbalanced for all levels of radiation $(400 \%, 600 \%, 800 \%, 1000 \%)$ and integration (PV1, PV2 + PV1 and PV2+PV1+PV3) as $0 \%$. The application of MPPT Fuzzy method shows that grid voltage on each phase for all levels of radiation and integration generator level still stable at 308 volts and results voltage unbalance $0 \%$. These results indicate that using both methods has not significant impact on changing of nominal unbalance voltage. If using MPPT $\mathrm{P}$ and $\mathrm{O}$ method, then the largest of average voltage harmonics $\left(\mathrm{THD}_{\mathrm{V}}\right)$ is generated on the condition of three PV generators connected to three phase grid (PV1+PV2+PV3) and radiation levels of $800 \mathrm{~W} / \mathrm{m} 2$ as $4.11 \%$. The smallest grid average voltage harmonics is generated on the condition of single PV generator connected to three-phase grid (PV1) and irradiance levels of $400 \mathrm{~W} / \mathrm{m} 2$ at $0.52 \%$. If using MPPT Fuzzy method, the largest average grid voltage harmonics is resulted on the condition of three PV generators connected to three-phase grid (PV1+PV2+PV3) and irradiance level of $1000 \mathrm{~W} / \mathrm{m} 2$ at $2.76 \%$. The smallest of average grid voltage harmonics is resulted on the condition of single PV generator connected to threephase grid (PV1) and irradiance levels of $400 \mathrm{~W} / \mathrm{m} 2$ at $0.23 \%$. Figure 11 and 12 shows that at the level of solar irradiance remains, the greater number of PV generator connected to three-phase grid, then average voltage harmonic will increases. Figure 13 also shows at solar radiation level is more increasing both using MPPT $\mathrm{P}$ and $\mathrm{O}$ and MPPT Fuzzy, then average grid voltage harmonics also will increase. The average grid voltage harmonics is reduced after using MPPT Fuzzy Method. Therefore, the application of MPPT Fuzzy is able to improve grid voltage harmonics $\left(\mathrm{THD}_{\mathrm{V}}\right)$ profile as a result of integration of $\mathrm{PV}$ generator to three phase grid.

Table 4 shows the use of MPPT $\mathrm{P}$ and $\mathrm{O}$ method results nominal of unbalance current for all irradiance $(400 \%, 600 \%, 800 \%, 1000 \%)$ and integration (PV1+PV2+PV3) level from 0\%, 1.73\%, and $15.385 \%$. At the same condition if using MPPT Fuzzy method produces an increase of current unbalance began to $0.1032 \%, 1.3940 \%$, and $19.048 \%$. These results indicate that the application of MPPT Fuzzy method produces unbalanced current value greater than MPPT Method P and O. If using MPPT P and $\mathrm{O}$ method, then the largest average grid current harmonics $\left(\mathrm{THD}_{\mathrm{I}}\right)$ generated on condition of three $\mathrm{PV}$ generator connected to three-phase grid (PV1+PV2+PV3) and irradiance levels of $800 \mathrm{~W} / \mathrm{m} 2$ at $1.94 \%$. At the same condition, the smallest average grid current harmonics is generated on condition of single PV generator connected to three-phase grid (PV1) and irradiance level of $400 \mathrm{~W} / \mathrm{m} 2$ at $0.07 \%$. If using MPPT Fuzzy method, the largest average grid current harmonics $\left(\mathrm{THD}_{\mathrm{I}}\right)$ resulted on the condition of three PV generators connected to three-phase grid (PV1+PV2+PV3) and irradiance level of $1000 \mathrm{~W} / \mathrm{m} 2$ at $1.68 \%$. The smallest value of $\mathrm{THD}_{\mathrm{I}}$ is generated on the condition of PV generator connected to three-phase grid (PV1) and irradiance levels of $400 \mathrm{~W} / \mathrm{m} 2$ at $0.04 \%$. Fuzzy MPPT method is able of improving value of input power factor better than MPPT P and O method. Table 4 shows at the level of solar iradiance remains, the greater number of PV generator connected to three-phase grid, then value of $\mathrm{THD}_{\mathrm{I}}$ will increases. At the level of solar irradiance is more increasing both using MPPT $\mathrm{P}$ and $\mathrm{O}$ and MPPT Fuzzy method, then value of $\mathrm{THD}_{\mathrm{I}}$ grid also increased. The average grid $\mathrm{THD}_{\mathrm{I}}$ is reduced after using MPPT Fuzzy method. Finally the application of MPPT Fuzzy is capable to enhance grid current harmonics profile due to integration of a number of PV generator to grid.

\section{CONCLUSION}

The method of MPPT $\mathrm{P}$ and $\mathrm{O}$ and MPPT Fuzzy on different irradiance and integration PV generator level produces unbalanced voltage value stable at $0 \%$. At the same conditions of use MPPT Fuzzy method results unbalanced current is greater than MPPT P and O method. On solar irradiance level fixed, the greater number of PV generator connected to three-phase grid, then values of average voltage and current harmonics (THD) will increases. At the level of solar radiation increases, average grid voltage and current THD also have increased. The average grid voltage and current THD is reduced after using MPPT Fuzzy method. Therefore the application of Fuzzy Logic Controller method for MPPT is able to improve the profile of grid voltage and current THD due to integration of a number of PV generator to three-phase grid corresponding IEEE Standard 519-1992. Fuzzy MPPT method is capable of improving input power factor better than MPPT P and $\mathrm{O}$ method.

\section{ACKNOWLEDGEMENTS}

The authors would like to acknowledge to Directorate of Research and Community Service, Ministry of Research, Technology, and Higher Education, Republic of Indonesia, for financial support through Research Competitive Grants or "Penelitian Hibah Bersaing" (PHB) 2016 (First Year) base on Letter Number 0581/E3/2016 date 24 Pebruary 2016 (Bacth 2). 


\section{REFERENCES}

[1] Almoataz Y. Abdelaziz, Hadi M. El-Helw, Basem Abdel Hamed., "Transient Analysis of Grid Connected Photovoltaic System Based on Comparative Study of Maximum Power Point Tracking Techniques", International Journal of Advances in Power Systems (IJAPS), ISSN: 2335-1772, Vol. 1, No. 3, Desember 2013.

[2] Mahmoud N. Ali, Mohammed F. El.-Gohary, "Grid Connected Photovoltaic Power Plant Controlled By Using FLC and CR With DC-DC Boost Converter", International Journal of Scientific Reseach Engineering and Technology (IJSRET), ISSN 2278-0882, Volume 3, Issue, 6 September 2014.

[3] S. Karunambigai, K Geetha, H.A. Shabeer, "Power Quality Improvement of Grid Connected Solar System", Journal of Scientific and Industrial Research, Vol. 74, June 2015, pp. 354-357.

[4] Zhou Chang and Shi Tao, "Power Quality Analysis of Photovoltaic Generation Integrated in User Side Grid", International Journal of Computer and Electrical Engineering, Vol. 5, No.2, April 2013. DOI: 10.7763/IJCEE.2013.V5.690.

[5] Prince Jose and Priya Rani Jos, "Grid Connected Photovoltaic System with Fuzzy Logic Control Based MPPT", International Journal of Engineering and Innovative Technology (IJEIT), ISSN: 2277-3754, Volume 3, Issue 8, February 2014.

[6] Amirullah, Ontoseno Penangsang, Adi Soeprijanto, "Power Quality Analysis of Integration Photovoltaic Generator to Three Phase Grid under Variable Solar Irradiance Level", TELKOMNIKA, Vol. 14, No. 1, March 2016, pp. 29 38, ISSN: 1693-6930, DOI: 10.12928/TELKOMNIKA.v14i1.3298.

[7] G. Bhanu Sree and D. Sunder Singh, "Power Quality Improvement in Three Phase Grid Connected System Integrated with Photovoltaic Cells using Fuzzy Controller", International Journal of Scientific Engineering and Technology Research, ISSN 2319-8885, Vol. 04, Issue 48, November 2015, Pages: 10426-10432.

[8] K.Ramalingeswara Rao, K.S. Srikanth, "Improvement of Power Quality using Fuzzy Logic Controller In Grid Connected Photovoltaic Cell Using UPQC", International Journal of Power Electronics and Drive Systems (IJPEDS), Vol 5 No 1, 2014 pages 101-111.

[9] Brahim Berbaoui, Samira Dib, Rachid Dehini, "Grid connected Photovoltaic Power Systems and Power Quality Improvement Based on Active Power Filter", TELKOMNIKA Indonesian Journal of Electrical Engineering, Vol 12 No 8, 2014 pages 5861-5868.

[10] Ali Reza Reisi, Muhammad H. Moradi, Hemen Showkati, "Combined Photovoltaic and Unified Power Quality Controller to Improve Power Quality”, Solar Energy, 88 (2013) 154-162, Available Online 3 January 2013, www.elsevier.com/locate/solener and www.sciencedirect.com.

[11] L. Siva Chaitanya Kumar and K. Padma, "Matlab/Simulink Based Modelling and Simulation of Residential Grid Connected Solar Photovoltaic", International Journal of Engineering Reseach and Technology (IJERT), ISSN: 2278-0181, Vol. 3. Issue 3, March-2014.

[12] Akash Garg, R. Saida Nayak, Susma Gupta, "Comparison of P \& O and Fuzzy Logic Controller in MPPT for Photovoltaic (PV) Applications by Using MATLAB/Simulink", IOSR Journal of Electrical and Electronics Engineering (IOSR-JEEE), e-ISSN: 2278-1676,p-ISSN: 2320-3331, Volume 10, Issue 4 Ver. I (July-Aug. 2015), PP 53-62 DOI: 10.9790/1676-10415362.

[13] J. Arrillaga, N.R. Watson, "Power System Harmonics", Second Edition, John Willey and Sons, Ltd, 2003.

[14] Tony Hoevenaar, P.Eng, Kurt LeDoux, P.E., Matt Colosino, 2003, "Interpreting IEEE Standart 519 and Meeting Its Harmonic Limit in VFD Application", Copyright Material IEEE Paper No. PCIC-2003-15.May, 2003.

[15] Thomas M. Bloming, P.E. and Daniel J. Carnovale, P.E., "Application of IEEE Standar 519-1992 Harmonic Limits", Presented at The 2005 IEEE IAS Pulp and Paper Industry Conference Appleton, WI.

[16] ANSI/IEEE 241, "IEEE Recommended Practice for Electric Power Systems in Commercial Buildings", 1990.

[17] S. Parthasarathy and Dr. Rajasekaran, "Harmonic Migitation in Rectifier System Using Hybrid Power System", International Conference on Computing, Electronics, and Electrical Technologies [ICCEET], 2012.

\section{BIOGRAPHIES OF AUTHORS}

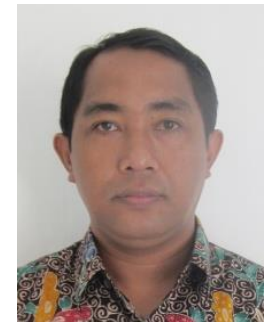

Amirullah was born in Sampang East Java Indonesis, in 1977. He received bachelor and master degree in electrical engineering from University of Brawijaya Malang and ITS Surabaya, in 2000 and 2008, respectively. He also worked as a lecturer in University of Bhayangkara Surabaya. He is currently working toward the doctoral degree, in electrical engineering in Power System and Simulation Laboratory (PSSL) ITS Surabaya. His research interest includes power system modeling and simulation, power quality, harmonic distortion, design of harmonic filter/power factor correction, and renewable energy. 


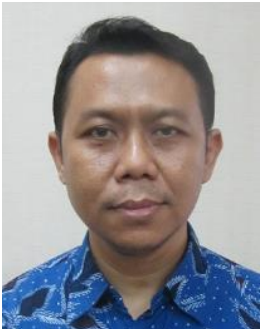

Agus Kiswantono was born in Malang East Java Indonesia, in 1971. He received bachelor and master degree in electrical engineering from Institut Teknologi Adhi Tama Surabaya (ITATS) and ITS Surabaya, in 1995 and 2009, respectively. He also worked as a lecturer in University of Bhayangkara Surabaya. His research interest includes power system modeling and simulation, application of artificial intelligent in power system and power distribution, as well as renewable energy in distributed generation. 